\title{
Extra-ovarian expression and activity of growth differentiation factor 9
}

\author{
Yao Wang ${ }^{1}$, Peter K Nicholls ${ }^{1,2}$, Peter G Stanton ${ }^{1,2}$, Craig A Harrison ${ }^{1,2}$, Mai Sarraj ${ }^{1}$, Robert B Gilchrist ${ }^{3}$, \\ Jock K Findlay ${ }^{1,4}$ and Paul G Farnworth ${ }^{1,5}$ \\ ${ }^{1}$ Prince Henry's Institute of Medical Research, PO Box 5152, Clayton, Victoria 3168, Australia \\ ${ }^{2}$ Department of Biochemistry, Monash University, Clayton, Victoria 3168, Australia \\ ${ }^{3}$ School of Paediatrics and Reproductive Health, Robinson Institute, University of Adelaide, Adelaide, South Australia 5005, Australia \\ ${ }^{4}$ Department of Obstetrics and Gynaecology and ${ }^{5}$ Department of Physiology, Monash University, Clayton, Victoria 3168, Australia \\ (Correspondence should be addressed to P Farnworth at Prince Henry's Institute of Medical Research; Email: paul.farnworth@princehenrys.org)
}

\begin{abstract}
Growth differentiation factor 9 (GDF9) produced within the ovary plays an essential role during follicle maturation through actions on granulosa cells, but extra-ovarian expression, signalling and actions of GDF9 are less well characterised. The present studies confirm GDF9 expression in the mouse testis, pituitary gland and adrenocortical cancer (AC) cells, and establish its expression in L $\beta \mathrm{T} 2$ gonadotrophs, and in mouse adrenal glands, particularly foetal and neonatal cortical cells. AC, L $\beta$ T2, TM3 Leydig and TM4 Sertoli cells express the requisite GDF9 binding signalling components, particularly activin receptor-like kinase (ALK) 5 and the bone morphogenetic protein (BMP)/GDF type II receptor, BMPRII (BMPR2). We therefore compared GDF9 activation of these potential extra-ovarian target cell types with its activation of granulosa cells. Recombinant mouse GDF9
\end{abstract}

stimulated expression of activin/transforming growth factor$\beta$-responsive reporters, pGRAS-luc or pAR3-lux, in TM4 and AC cells (IC50 $=145 \mathrm{ng} / \mathrm{ml}$ in the latter case), and two granulosa cell lines, KGN and COV434. The ALK4/5/7 inhibitor, SB431542, blocked GDF9 activity in each case. By contrast, GDF9 lacked specific effects on TM3 cells and rat primary pituitary and mouse L $\beta$ T2 gonadotrophs. Our findings show that GDF9 regulates the expression of R-SMAD2/3-responsive reporter genes through ALK4, 5 or 7 in extra-ovarian (adrenocortical and Sertoli) cells with similar potency and signalling pathway to its actions on granulosa cells, but suggest that expression of BMPRII, ALK5 (TGFBR 1) and R-SMADs 2 and 3 may not be sufficient for a cell to respond to GDF9.

Journal of Endocrinology (2009) 202, 419-430

\section{Introduction}

The transforming growth factor- $\beta$ (TGF- $\beta$ or TGFB), superfamily of growth and differentiation factors are dimeric proteins that display a wide range of context-dependent local actions within diverse tissues (Massague 1998, Chang et al. 2002). Agonists of this superfamily generally signal by bringing distinct combinations of type I and type II serine/ threonine kinase receptors together to form heteromeric complexes (Massague 1998, Piek et al. 1999). Amongst the type II receptors, ActRII and ActRIIB (listed as ACVR2B in MGI Database) mediate signals for activins and some bone morphogenetic proteins (BMPs), and BMPRII (listed as BMPR2 in MGI Database) mediates signals for most BMP and growth/differentiation factor (GDF) isoforms, whereas TRRII (listed as TGFBR2 in MGI Database) is exclusively used by TGF- $\beta$ isoforms (Massague 1998, Piek et al. 1999, de Caestecker 2004). Each agonist ligand promotes the pairing of its preferred type II receptor(s) with matching subsets of type I activin receptor-like kinase (ALK) receptors (listed as ACVR in MGI Database), leading to downstream phosphorylation of pathway-specific intracellular receptor-activated (R-) SMADs. Signals from ALK1, 2, 3 and 6 are transduced by R-SMADs 1, 5 and 8, whereas those from ALK4, 5 and 7 are transduced by R-SMADs 2 and 3 .

GDF9 is a TGF- $\beta$ superfamily agonist noted for its high and selective expression by oocytes within the ovary (McGrath et al. 1995), where its signals to surrounding cumulus granulosa cells are required for folliculogenesis to progress beyond the primary follicle stage (Gilchrist \& Thompson 2007). In the GDF9 null mouse, granulosa cells stop proliferating but cannot undergo apoptosis, and display an altered differentiation pattern (Dong et al. 1996, Elvin et al. 1999, Hanrahan et al. 2004). Gdf9 mRNA expression has also been identified in extra-ovarian sites, including the pituitary, hypothalamus, placenta, testis and adrenal, and in mouse adrenocortical cancer (AC) and Leydig (I-10) cell lines (Fitzpatrick et al. 1998, Pennetier et al. 2004, Faure et al. 2005, Farnworth et al. 2006b, Lee et al. 2007a), but studies of GDF9 actions have focused almost exclusively on the ovary. 
By manipulating the cellular expression or interaction of various receptor pairs, Hsueh et al. deduced that GDF9 signals through an unusual combination of BMPRII and ALK5, the classical type I receptor for TGF- $\beta$, to R-SMADs 2 and 3 (Vitt et al. 2002, Mazerbourg et al. 2004), and findings in the physiological context of granulosa cells are consistent with this suggestion (Kaivo-Oja et al. 2003, Roh et al. 2003, Gilchrist et al. 2006). This pathway is atypical for the BMP/GDF family of ligands, nearly all of which signal via R-SMADs $1 / 5 / 8$ (de Caestecker 2004). We previously found that AC cells, L $\beta$ T2 gonadotrophs, TM3 Leydig cells and TM4 Sertoli cells express mRNA encoding the requisite binding/signalling proteins for GDF9 (Farnworth et al. 2007). Taken together, these findings raised the possibility that GDF9 acts locally in the adrenal cortex, pituitary gland and testis. AC and L $\beta \mathrm{T} 2$ cells remarkably express ALK5 in the absence of T $\beta R I I$, potentially making them ideal models for dissecting GDF9 actions without interference from endogenous TGF $\beta$ (Ethier et al. 2002, Farnworth et al. 2007).

In the present study, we have confirmed and extended the identification of extra-ovarian tissues and cell types that express GDF9, examined the ontogeny of GDF9 expression in the adrenal, and compared GDF9 activation of extra-ovarian cell types that express the identified GDF9 binding/signalling species with its activation of human granulosa KGN and COV434 cells as examples of established GDF9 target cells. The results support the proposal that GDF9 signals via BMPRII, ALK5 and R-SMADs2/3 to activate AC and TM4 Sertoli cells. However, contrary to predictions, gonadotrophs and TM3 Leydig cells did not respond specifically to GDF9 for several measured endpoints.

\section{Materials and Methods}

\section{Materials}

The mouse TM3 and TM4 (Mather 1982), L $\beta$ T2 (Pernasetti et al. 2001), AC (Rilianawati et al. 1998, Rahman et al. 2001, Farnworth et al. 2006b), COV434 (Zhang et al. 2000) and KGN (Nishi et al. 2001) cell lines were obtained as previously described (Farnworth et al. 2006b, 2007, Chand et al. 2007). Rats and mice were obtained from Central Animal House, Monash University (Clayton, Victoria, Australia). Adult mice and male rats were maintained under standard conditions, with free access to food and water, whereas foetal and neonatal mice were killed by cervical dislocation on the day they were obtained. The studies were performed in accordance with the Australian Code of Practice for the Care and Use of Animals for Scientific Purposes, and procedures were approved by the Monash Medical Centre Animal Experimentation Ethics Committee. Purified recombinant human inhibin A (31 kDa monoglycosylated form) and inhibin $\mathrm{B}$ (mixture of 31 and $34 \mathrm{kDa}$ forms) were isolated as previously described, and both preparations were well characterised with respect to potency in the classical rat pituitary cell culture bioassay (Makanji et al. 2007). Isoforms of recombinant human activin $(\mathrm{A}, \mathrm{B}, \mathrm{AB})$ and $\mathrm{BMP}(-6$, -7 ) were obtained from R\&D Systems (Minneapolis, MN, USA), TGF- $\beta$ isoforms (1 and 2) were obtained from PeproTech Inc. (Rocky Hill, NJ, USA). A partially purified preparation of recombinant mouse GDF9 that was generated from a transfected human embryonic kidney $293 \mathrm{H}$ cell line, and a matching conditioned medium preparation lacking GDF9 $(293 \mathrm{H}$ control), were prepared as previously described (Gilchrist et al. 2004, 2006, Hickey et al. 2005). The bioactivity of the mouse GDF9 preparation has previously been established in rat granulosa cell proliferation and reporter expression assays (Gilchrist et al. 2004, 2006). The concentrations of mouse GDF9 were determined by immunoanalysis using a rat GDF9 preparation as the standard (Gilchrist et al. 2004). A GDF9 immunoactivity of $50 \mathrm{ng} / \mathrm{ml}$ approximately corresponds to $2 \mathrm{nM}$ protein dimer. SB431542, a synthetic inhibitor of ALK 4, 5 and 7 (Inman et al. 2002), was from Tocris Cookson Ltd (Northpoint, Fourth Way, Avonmouth, UK). Reagents and materials for RNA extraction and realtime RT-PCR amplification were as previously described (Farnworth et al. 2006b). Primers for gene amplification were made commercially (Sigma-Genosys). Goat anti-mouse GDF9 IgG (cat. no. NR-01-0095; a/b\#1) was from RayBiotech, Inc. (Norcross, GA, USA), as was mouse anti-human BMP-15 IgG (cat. no. NR-01-0018; a/b\#2). Rabbit anti-human GDF9 IgG (raised against N-terminal peptide sequence; cat. no. ab38544; $\mathrm{a} / \mathrm{b} \# 3$ ) was from $\mathrm{Abcam}$ plc (Cambridge, UK), and goat anti-human GDF9 (C-18) IgG (raised against C-terminal peptide sequence; cat. no. sc-12244; a/b\#4) was from Santa Cruz Biotechnology, Inc. (Santa Cruz, CA, USA). The $3 \times$ GRAS-PRL-lux (pGRASluc) reporter construct (Ellsworth et al. 2003) was kindly provided by Dr Buffy S Ellsworth (Colorado State University, Fort Collins, CO, USA). This and additional luciferase reporter constructs and co-factors (pAR3-lux, containing an activin and TGF- $\beta$ response element from the Xenopus Mix.2 gene (Hayashi et al. 1997); FAST2, required for pAR3-lux expression in many cell types) were employed as previously described (Ethier et al. 2002, Gilchrist et al. 2006, Chand et al. 2007).

Culture and treatment of cell lines and rat primary pituitary and adrenal cells

Primary cultures of adult (60-90-days old) male rat anterior pituitary and adrenal cells were prepared and maintained as previously described (Farnworth et al. 1988, 2006b). Primary cultures and all cell lines were cultured in a 1:1 (vol:vol) mixture of DMEM:F12 media buffered with sodium bicarbonate, and containing non-essential amino acids for MEM, and supplementary glutamine $(2 \mathrm{mmol} / \mathrm{l}$ final $)$. Medium was supplemented with $10 \%$ FBS for passaging and pre-incubations and, for AC cells, also included HEPES buffer $(10 \mathrm{mmol} / \mathrm{l})$. Cells were maintained at $37^{\circ} \mathrm{C}$ in a humidified atmosphere of $5 \% \mathrm{CO}_{2}$ in air. 
Following plating, cells were pre-incubated for 1 day in FBS-containing medium, then culture medium was changed to a chemically defined medium containing antibiotics, and $10 \%$ artificial serum (AS) that includes insulin, transferrin and BSA, as previously described (Farnworth et al. 2006b, 2007). Unless otherwise indicated, treatments or matching vehicle(s) were applied to cells overnight under standard culture conditions in this chemically defined AS-containing medium prior to the analyses. Activin, BMP, TGF- $\beta$ and inhibin isoforms and GDF9 were tested at single concentrations that were maximally active in other assays in our laboratory $(\geq 2, \geq 2,0.4$ and $0.05 \mathrm{nM}$, and $50 \mathrm{ng} / \mathrm{ml}$ respectively; Farnworth et al. 2006a, 2007, Gilchrist et al. 2006), unless otherwise indicated.

\section{Immunoassay of rat and mouse FSH}

After a 3-day treatment period, the conditioned media samples from rat primary pituitary cell cultures were collected, the cells were lysed, and both medium and lysate samples were subsequently assayed for FSH by RIA as previously described (Mason et al. 1996), using goat secondary antibody precipitation with the following reagents, kindly provided by the NIDDK: rat FSH-RP-2 (Lot \#AFP-4621B) as standard; rat FSH-I-8 (Lot \#AFP-11454B) for preparing the tracer, which was iodinated using iodogen, and rabbit anti-rat FSH-S-11 (Lot \#AFP-C0972881) as the primary antiserum. The mouse FSH levels in L $\beta \mathrm{T} 2$ cell-conditioned media samples were measured by ELISA as previously described (Farnworth et al. 2006b, Makanji et al. 2007).

\section{$m R N A$ purification and real-time PCR analyses}

Total RNA extracted from whole dissected pituitary and adrenal glands (or pools of glands in the cases of foetal and neonatal mouse adrenal), a portion of dissected testis or cell monolayers $\left(2 \times 10^{6}\right.$ cells $/ 5 \mathrm{ml}$ medium/well in 6-well $(3.5 \mathrm{~cm}$ diameter) cluster dishes) using UltraSpec RNA reagent was purified using standard procedures, and cDNAs were synthesised from $2 \mu \mathrm{g}$ RNA by oligo(dT) priming using $50 \mathrm{U}$ of Expand Reverse Transcriptase as previously described (Farnworth et al. 2006a, 2007). In the foetal and neonatal mouse adrenal samples, $0.6 \mu \mathrm{g}$ RNA was used. Primers for amplification of specific cDNA products were as follows: mouse GDF9 (forward primer, 5'-AACCCAGCAGAAGTCACCTC $-3^{\prime}$; reverse primer, 5'-AGGGGCTGAAGGAGGGAGG-3'), yielding a 337 bp product; rat GDF9 (forward primer, 5'-GGCTCCCAGCAACCAGATGACA-3 ${ }^{\prime}$; reverse primer, $5^{\prime}$-TGGCGCTCTTGGGGTAGCCTTG-3'), yielding a 208 bp product. Primers for amplification of mouse glyceraldehyde-3-phosphate dehydrogenase (Gapdh) as a housekeeping gene were as previously described (Drummond et al. 2000, Farnworth et al. 2006b, 2007).

Real-time PCR amplification assays were performed in a Rotor-Gene RG-3000 (Corbett Research, Mortlake, NSW,
Australia; Farnworth et al. 2007). The amplification and assessment run for mouse (or rat) GDF9 consisted of: 1) denaturation at $95^{\circ} \mathrm{C}$ for 8 (6) $\mathrm{min}$ to activate the Taq polymerise, 2) amplification and quantification for 40 cycles of $15 \mathrm{~s}$ at $95^{\circ} \mathrm{C}$ for denaturation, $5 \mathrm{~s}$ at $62(69){ }^{\circ} \mathrm{C}$ for annealing, $17(10) \mathrm{s}$ at $72{ }^{\circ} \mathrm{C}$ for extension, and a single fluorescence measurement at $72{ }^{\circ} \mathrm{C}$ for quantitation, 3) melting curve assessment between 57 and $95^{\circ} \mathrm{C}$ at a temperature transition rate of $0.2^{\circ} \mathrm{C}$ per s with a continuous fluorescence measurement, and 4) cooling to $40^{\circ} \mathrm{C}$. Under these conditions, a GDF9 transcript of the expected size was amplified in each case. Procedures for assay validation, and qualitative assessment of real-time RT-PCR products have been previously described (Farnworth et al. 2006b, 2007).

\section{Immunohistochemical analyses of GDF9 expression in mouse tissues}

Ovary (adult), pituitary gland (adult, both male and female) and adrenal glands from mice of various ages (foetal $(14.5$ and 16.5 days post-coitum), neonatal, 15 -days old and adult) were excised, immersion-fixed in Bouin's solution and processed for light microscopy as described elsewhere (Nicholls et al. 2009). The primary antibody preparation was goat antihuman GDF9 (C-18) IgG from Santa Cruz Biotechnology, Inc. (see above for details) used at a final concentration of $0 \cdot 20 \mu \mathrm{g} / \mathrm{ml}$. Specificity of staining was examined by substituting the primary antibody with an equivalent dilution of pre-immune goat immunoaffinity-purified $\operatorname{IgG}$, and by co-incubation of sections with primary antibody and a GDF9 blocking peptide, as previously described (Nicholls et al. 2009).

\section{Transient transfections and assay of luciferase activity}

Each cell type was transiently transfected with several activin/TGF- $\beta$-responsive reporter constructs to examine its responsiveness to activin $\mathrm{A}$ and/or TGF- $\beta$ as positive controls. After determining the optimal reporter for each cell line, AC, TM3, L $\beta$ T2 and KGN cells were routinely transfected with the pGRAS-luc reporter construct $(800 \mathrm{ng}$ DNA per well), and TM4 and COV434 cells were transfected with a mixture of pAR3-luc reporter (700 ng DNA per well) and FAST2 transcription co-factor (100 ng DNA per well) using Lipofectamine 2000. Cultures of KGN cells $(90 \%$ confluent in $75 \mathrm{~cm}^{2}$ flasks) were transfected with liposomes generated between $8 \mu \mathrm{g}$ reporter construct DNA and $20 \mu \mathrm{l}$ Lipofectamine in a total volume of $2 \mathrm{ml}$ serum- and antibiotic-free medium overnight. In all other cases, cells in suspension $\left(0 \cdot 15-0 \cdot 3 \times 10^{6}\right.$ cells $/ 620 \mu \mathrm{l}$ FBS-containing medium per well) were mixed with the liposome solution at a DNA:lipofectamine ratio of 1:4 or 1:5 (mass:volume) at $80 \mu 1$ per well, then seeded in 24 -well plates and incubated for $24 \mathrm{~h}$. The transfection medium was subsequently replaced with fresh medium containing 10\% FBS and antibiotics, and incubated overnight. Transfected cultures were then 
incubated for $6 \mathrm{~h}$ in medium containing 10\% AS and antibiotics, with or without treatments (see table and figure legends for details). Preparation of cell lysates and assay of luciferase levels were performed as previously described (Ethier et al. 2002).

\section{Statistical analyses}

Concentration-response curves were fitted, maximum/ minimum effects and median effective/inhibitory concentrations (EC50/IC50) were determined by non-linear regression, and statistical analyses were performed using GraphPad Prism (GraphPad Software Inc., CA, USA). Treatment effects on luciferase levels were replicated in separate experiments (see table and figure legends for details). After establishing homogeneity of variance across the dataset for each endpoint, mean data were compared using one-way ANOVA followed by post-hoc Neuman-Keuls Multiple Comparison Test, or unpaired Student's $t$-test where appropriate, and $P<0.05$ was considered significant.

\section{Results}

\section{Pituitary, adrenal and gonadal expression of GDF9 and its} signalling components

Gdf9 mRNA was detected by PCR in rat ovary (as the positive control) and rat primary pituitary cells in culture (Fig. 1A), confirmed by sequencing of the predicted $208 \mathrm{bp}$ product. Assays with primers specific for mouse $G d f 9 \mathrm{mRNA}$ showed expression in adult mouse ovary $(\mathrm{o})$, testis $(\mathrm{t})$ and, to a minor extent, pituitary (p; Fig. 1B, lanes $2-4$ respectively), confirmed by sequencing of the predicted $337 \mathrm{bp}$ product. Gdf9 mRNA was also detected in pooled adrenal glands obtained from female mouse foetuses at 14.5 days postcoitum (dpc; $a_{f}$, Fig. 1B, lane 5), and adrenal tissue from neonatal and juvenile (5-day old) female mice $\left(a_{n}\right.$ and $a_{j}$ respectively; Fig. 1B, lanes 6 and 7), but was on the threshold of detection in adult female $\left(\mathrm{a}_{\mathrm{a}}\right)$ or male $\left(\mathrm{a}_{\mathrm{a}}{ }^{\mathrm{r}}\right)$ mouse adrenal (Fig. 1B, lanes 8 and 9 respectively). GAPDH cDNA was nevertheless amplified from samples that were negative for Gdf9 (lower panel of Fig. 1B). Gdf9 mRNA was readily detected in the L $\beta \mathrm{T} 2$ gonadotroph and $\mathrm{AC}$ cell lines, whereas expression by TM3 Leydig and TM4 Sertoli cells was minor (Fig. 1C). No product was obtained from any of these samples after the 40 cycles of amplification in the absence of reverse transcriptase (e.g. Fig. 1C). TM3, TM4, AC and $\mathrm{L} \beta \mathrm{T} 2$ cell lines all express the mRNA species that encode BMPRII, ALK5 and SMADs 2 and 3, the previously identified signalling components for GDF9, along with the requisite signalling components for activin and BMP (Farnworth et al. 2007)

A commercially available affinity purified $\operatorname{IgG}$ directed against C-terminal peptide GDF9 (a/b \#4) was used to examine the expression of GDF9 protein in the mouse pituitary and adrenal glands, with the adult mouse ovary as a
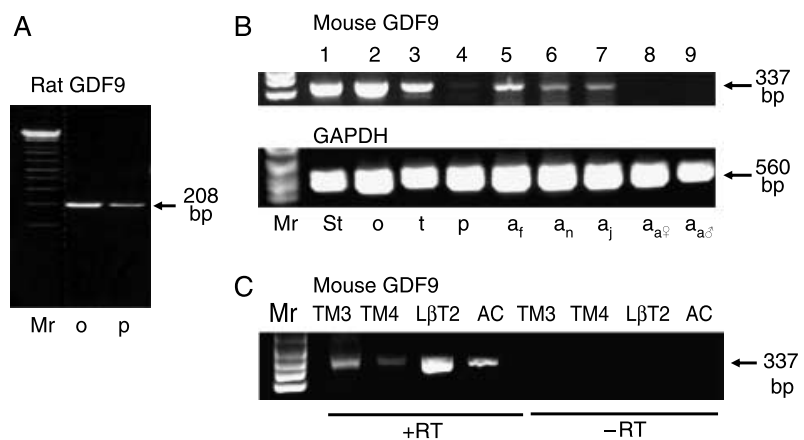

Figure 1 Presence of mRNA encoding GDF9 in rat and mouse tissues and cells. (A) Rat GDF9 products (208 bp) were obtained by RT-PCR from total RNA of whole ovary (o) and a primary pituitary cell culture ( $p$ ) from adult rats. (B) RT-PCR primers for mouse GDF9 yielded products (337 bp; upper panel) from the purified mouse GDF9 CDNA standard derived from ovarian RNA (St, lane 1), and from total RNA extracted from adult mouse ovary (o, lane 2), testis $(\mathrm{t}$, lane 3 ) and pituitary gland ( $\mathrm{p}$, lane 4$)$, adrenal glands obtained from foetal (day 14.5 post-coitum; $a_{\mathrm{f}}$ lane 5 ), neonatal (day $0 ; a_{n}$, lane 6), juvenile (day 5; $a_{j}$, lane 7) and adult female ( $a_{q}$, lane 8 ) mice, and the adult male mouse ( $a_{0}$, lane 9$)$. Primers for mouse GAPDH yielded products (560 bp; lower panel) from all of these tissues. (C) RT-PCR primers for mRNA species encoding mouse GDF9 yielded 337 bp products from mouse Leydig TM3, Sertoli TM4, L $\beta$ T2 gonadotroph, and adrenocortical cancer (AC) cells. + RT and - RT signify amplification yields after the inclusion and omission respectively, of reverse transcriptase. Molecular weight markers $(\mathrm{Mr})$ were run in the first lane of each ethidium bromidestained $1.7 \%$ agarose gel.

positive control. Low magnification photomicrographs of ovary sections show intense staining of oocytes within pre/antral follicles (Fig. 2A), and this was abolished by co-incubation with competitor peptide (Fig. 2B). In the adult male anterior pituitary, high magnification photomicrographs show strong staining of clusters and larger aggregates of cells in sections in which approximately two-thirds of the cells were positive for GDF9 (Fig. 2C). This staining was cytoplasmic, mainly punctate or granular in distribution (Fig. 2C), and was greatly attenuated by the competitor peptide (Fig. 2D, in which the inset additionally shows the lack of staining with a non-specific $\operatorname{IgG}$ applied at a matching concentration). Figure 2E shows a section of adult female pituitary with strong cytoplasmic staining within the majority of the anterior pituitary lobe, similar to the picture in the male, while the neurointermediate lobe shows more diffuse staining. Staining in both lobes of the pituitary was attenuated by the blocking peptide (e.g. Fig. 2F).

At $14.5 \mathrm{dpc}$, the foetal male adrenal was mainly composed of cells that showed strong cytoplasmic staining for GDF9, interspersed with unstained cells (Fig. 2G), and the staining was reduced by the GDF9 competitor peptide (Fig. 2H). Primordial cortical and medullary zones were evident in the male adrenal gland at $16.5 \mathrm{dpc}$ : medullary cells were unstained, whereas intense cytoplasmic staining was present in cortical cells, especially those adjacent to the medulla 

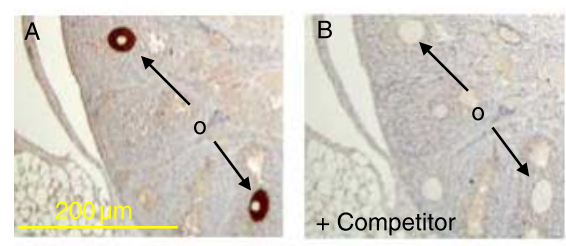

Adult ovary $\times 20$

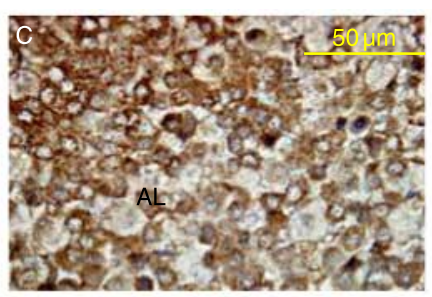

Adult male pituitary $\times 100$
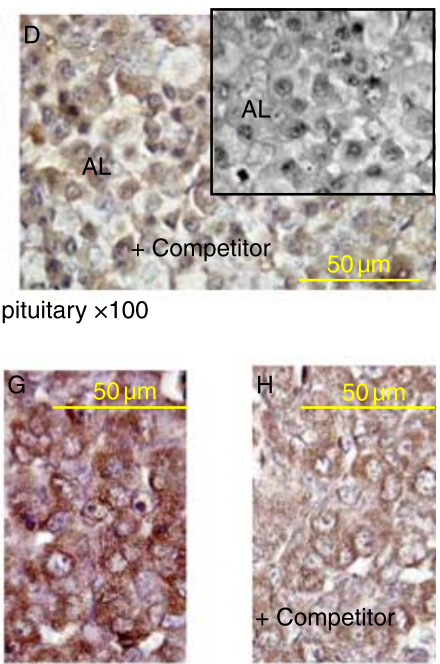

14.5 dpc male adrenal $\times 100$

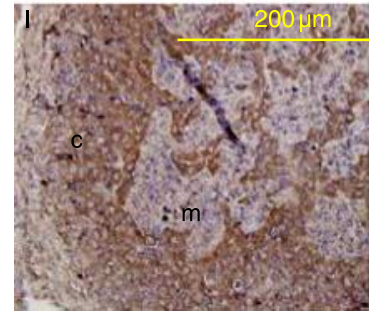

$16.5 \mathrm{dpc}$ male adrenal $\times 40$

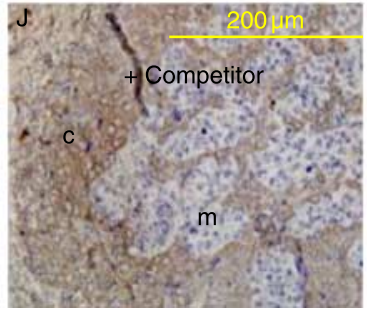

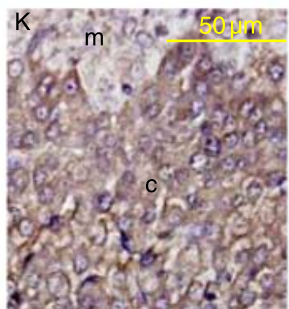

Day 15 female adrenal $\times 100$

Figure 2 Immunohistochemical localisation of GDF9 in mouse tissues. (A) Adult ovary (magnification $\times 20$ ) as positive control shows intense cytoplasmic staining of oocytes (o) within preantral/antral follicles. (B) Such staining was blocked by inclusion of a GDF9 peptide competitor. (C) Anterior lobe $(\mathrm{AL})$ of adult male pituitary gland $(\times 100)$ shows dark cytoplasmic staining of at least half the cells, most of which are in clusters between unstained cells. (D) Application of the competitor peptide blocked staining in the anterior lobe. The inset to panel D shows the lack of staining when the primary antibody was replaced by pre-immune goat serum IgG. (E) A section of adult female pituitary $(\times 40)$ shows intense cytoplasmic GDF9 staining of many anterior lobe cells, and more diffuse staining of cells within the neorointermediate lobe (NIL). (F) Staining of cells in both lobes was greatly reduced by the competitor peptide $(\times 40)$ and pre-immune lgG provided no staining (inset to panel F). (G) The foetal male adrenal gland at 14.5 days post-coitum $(\times 100)$ included unstained cells and cells with strong cytoplasmic staining for GDF9. (H) Such staining was attenuated by the competitor peptide. (I) By 16.5 days post-coitum, the adrenal ( $X 40$ ) showed segregation of unstained medullary zone $(\mathrm{m})$ cells from GDF9-positive cortical cells (c), with strongest staining in the juxtamedullary cells of the X-zone. (J) Staining of these cortical cells was reduced by competitor peptide. (K) Cortical cells in the 15 days postnatal female adrenal gland $(\times 100)$ showed staining for GDF9, in contrast to the medulla. (L) The competitor peptide displaced some cortical staining. The inset to panel $L(\times 40)$ shows absence of staining of cortical and medullary adrenal cells in the absence of the primary antibody. The bar in each panel represents either $200 \mu \mathrm{m}(\mathrm{A}, \mathrm{B}, \mathrm{E}, \mathrm{F}, \mathrm{I}, \mathrm{L})$ or $50 \mu \mathrm{m}$, as indicated. Full colour version of this figure available via http://dx.doi.org/10.1677/JOE-08-0563.

(Fig. 2I), and that staining was reduced by the competitor (Fig. 2J). Adrenocortical cells of female adrenal glands at postnatal day 15 showed a small amount of specific staining for GDF9, but the medullary cells were again negative (compare Fig. 2, panels $\mathrm{K}$ and L), and a similar pattern was observed in the adult adrenal glands from both sexes (data not shown).

Comparison of luciferase reporter responses to GDF9 in granulosa and extra-ovarian cell types

Human COV434 granulosa cells were transiently transfected with the pAR3-lux reporter, and KGN granulosa cells were transiently transfected with pGRAS-luc to validate the responses of these reporters to GDF9 in its established target cell type. In COV434 granulosa cells, luciferase expression was significantly stimulated $3 \cdot 4-$ and $2 \cdot 4$-fold by treatment for $6 \mathrm{~h}$ with activin A $(2 \mathrm{nmol} / \mathrm{l})$ and GDF9 $(50 \mathrm{ng} / \mathrm{ml})$ respectively, whereas the GDF9 control preparation derived from $293 \mathrm{H}$ cell-conditioned medium $(293 \mathrm{H}$ control) was without significant effect (Table 1). A similar pattern was observed in KGN cells (Table 1).

GDF9 significantly increased pAR3-lux expression in TM4 cells by $2 \cdot 5$-fold, similar to stimulation elicited by activin $\mathrm{A}(3 \cdot 3$-fold increase), and by activins $\mathrm{B}$ and $\mathrm{AB}$ (average increases in 3.0- and 3.8-fold respectively; Table 1 ). The pattern of responses mimicked that seen in the granulosa 
Table 1 Effects of transforming growth factor (TGF)- $\beta$ superfamily members on the level of pAR3-lux or pGRAS-luc expression in granulosa and extra-ovarian cell types. Cells that had been transiently transfected with either reporter were treated 1 day later with medium alone (control), growth/differentiation factor (GDF)-9, its conditioned medium control $(293 \mathrm{H})$, or the indicated isoforms of activin or transforming growth factor (TGF)- $\beta$ for $6 \mathrm{~h}$, after which luciferase levels were determined in duplicate for replicate wells. Results (fold matching untreated control) from $(n)$ replicate experiments are mean \pm s.E.M., except where indicated

\begin{tabular}{|c|c|c|c|c|c|c|}
\hline \multirow{2}{*}{$\begin{array}{l}\text { Reporter } \\
\text { Cell line }\end{array}$} & \multicolumn{2}{|l|}{ pAR3-lux } & \multicolumn{4}{|l|}{ pGRAS-Iuc } \\
\hline & COV434 & TM4 & $\mathrm{KGN}$ & L $\beta \mathrm{T} 2$ & $\mathrm{AC}$ & TM3 \\
\hline \multicolumn{7}{|l|}{ Treatment } \\
\hline Control & $1 \cdot 00$ & $1 \cdot 00$ & $1 \cdot 00$ & $1 \cdot 00$ & $1 \cdot 00$ & $1 \cdot 00$ \\
\hline $293 \mathrm{H}$ & $0 \cdot 95 \pm 0 \cdot 05(3)$ & $1 \cdot 16 \pm 0 \cdot 07(3)$ & $1 \cdot 05(2)$ & $0.94 \pm 0.03$ & $1 \cdot 08 \pm 0 \cdot 02$ & $1 \cdot 4(2)$ \\
\hline GDF9 (50 ng/ml) & $2 \cdot 4 \pm 0 \cdot 2^{*,+}(3)$ & $2 \cdot 5 \pm 0 \cdot 2 *(3)$ & $1 \cdot 9(2)$ & $1 \cdot 09 \pm 0.07(3)$ & $15 \cdot 9 \pm 1 \cdot 5^{*,+}(3)$ & $1 \cdot 3(2)$ \\
\hline Activin A (2 nM) & $3 \cdot 4 \pm 0 \cdot 5 *(3)$ & $3 \cdot 3 \pm 0 \cdot 1 *(4)$ & $3 \cdot 2 \pm 0 \cdot 4 *(5)$ & $1 \cdot 7 \pm 0 \cdot 4(3)$ & $15 \cdot 5 \pm 2 \cdot 6^{*}(6)$ & $4 \cdot 8 \pm 0 \cdot 7 *(4)$ \\
\hline Activin B (2 nM) & ND & $3 \cdot 0(2)$ & $1 \cdot 4(1)$ & $1 \cdot 3(1)$ & $13 \cdot 9 \pm 0 \cdot 4^{*}(3)$ & $2 \cdot 2 \pm 0 \cdot 6(3)$ \\
\hline Activin AB (2 nM) & ND & $3 \cdot 8(2)$ & $4 \cdot 1(1)$ & $1 \cdot 3(1)$ & $21 \cdot 6 \pm 5 \cdot 7^{*}(3)$ & $4 \cdot 0 \pm 0 \cdot 8(3)$ \\
\hline TGF- $\beta 1(0 \cdot 4$ nM) & ND & $11 \cdot 8 \pm 2 \cdot 8^{*}(3)$ & $6 \cdot 7(1)$ & ND & $1 \cdot 15(2)$ & $8 \cdot 8 \pm 1 \cdot 9 *(4)$ \\
\hline TGF- $\beta 2(0 \cdot 4 \mathrm{nM})$ & ND & $12(2)$ & ND & ND & $1 \cdot 1(1)$ & $7 \cdot 6(2)$ \\
\hline
\end{tabular}

ND, not determined. ${ }^{*}{ }^{+}$Signify results that significantly differ from the untreated control group $(=1)$, and the matching $293 \mathrm{H}$ control treatment group, respectively $(P<0 \cdot 05)$.

cell lines (Table 1). Both TM4 and KGN cells also displayed robust responses to TGF- $\beta$ (Table 1 ). In contrast to the granulosa and Sertoli cell models, L $\beta$ T2 gonadotrophs responded poorly to GDF9, although activin A significantly stimulated pGRAS-luc expression (Table 1).

AC cells transfected with pGRAS-luc were tested for responses to $6 \mathrm{~h}$ treatment with TGF- $\beta$ superfamily agonists. GDF9 increased luciferase expression 16-fold above that in the untreated control, showing similar activity to activins A, B and AB (16-, 14- and 22-fold increases respectively (Table 1), whereas the $293 \mathrm{H}$ control sample, BMP-6 (2 nmol/l) and BMP-7 (4 nmol/1; data not shown) had no significant effects. These results for AC cells confirmed the specificity of pGRAS-luc responses to activators of R-SMADs 2 and 3 . Note that the failure of AC cells to respond to R-SMAD 2/3activating TGF- $\beta$ isoforms (each 0.4 nmol/1; Table 1 ) reflects their lack of T $\beta$ RII expression (Farnworth et al. 2007), and provides additional negative controls in this experiment.

GDF9 did not elicit any greater response than the $293 \mathrm{H}$ control in TM3 cells (Table 1), indicating that there was no specific response to the agonist. Activins $A, B$ and $A B$ nevertheless increased TM3 cell expression of pGRAS-luc by $2 \cdot 2$ - to $4 \cdot 8$-fold, and TGF- $\beta$ isoforms increased expression of the reporter by almost 10-fold (Table 1). The latter results provided evidence of functional ALK5 receptors in TM3 cells, and indicated their capacity to respond to R-SMAD 2/3-activating ligands other than GDF9.

\section{GDF9 potency, specificity and signalling pathway in extra-ovarian cell types}

GDF9 stimulated pGRAS-luc expression in AC cells in a concentration-dependent manner $(E C 50=145 \pm 42 \mathrm{ng} / \mathrm{ml}$; mean \pm s.E.M., $n=3$; Fig. $3 \mathrm{~A}$ ), similar to the pattern seen for stimulation of CAGA-luc expression by the same GDF9 preparation in transiently transfected mouse granulosa cells $(\mathrm{EC} 50=80 \mathrm{ng} / \mathrm{ml}$ by analysis of data from (Gilchrist et al. 2006); computed curve shown for comparison in Fig. 3A). Matching high concentrations of the $293 \mathrm{H}$ control lacked effect in the pGRAS-luc assay (Fig. 3A).

The affinity purified $\operatorname{IgG}(4 \mu \mathrm{g} / \mathrm{ml})$ directed against recombinant mouse GDF9 abolished the stimulation of pGRAS-luc expression by the mouse GDF9 preparation (used at $25 \mathrm{ng} / \mathrm{ml}$, to clearly show the dependence of immunoneutralisation on antibody concentration) in $\mathrm{AC}$ cells (Fig. 3B, a/b \#1). At $4 \mu \mathrm{g} / \mathrm{ml}$, the antibody was equally effective against $50 \mathrm{ng} / \mathrm{ml}$ GDF9 (data not shown). However, this antibody did not significantly affect luciferase expression that was induced by activin isoforms (each $1 \mathrm{nmol} / \mathrm{l}$ ) under similar conditions (Fig. 3C). An affinity purified polyclonal antibody raised against a human GDF9 N-terminal sequence showed only minor immunoneutralising activity $(\mathrm{a} / \mathrm{b} \# 3$ in Fig. 3C), whereas the antibodies raised against a C-terminal sequence of human GDF9 (data not shown) and recombinant human BMP-15 (a/b \#2 in Fig. 3B) lacked immunoneutralising activity. Thus, the actions of the partially purified GDF9 preparation were fully accounted for by the specified ligand.

The stimulation of pGRAS-luc expression by GDF9 and activin in AC cells was abolished by pre- and concurrent treatment of the cells with the ALK4/5/7 inhibitor, SB431542 (20 $\mathrm{MM}$; Fig. 4A), consistent with the proposed signalling pathways for these agonists. Neither the $293 \mathrm{H}$ control (Fig. 4A) nor BMP-6 alone (data not shown) significantly stimulated luciferase expression, and dimethyl sulfoxide, the vehicle for SB431542, added at a matching concentration did not modify any of the responses (Fig. 4A). GDF9 and activin isoform induction of luciferase reporter expression in TM4 Sertoli cells were likewise antagonised by SB431542 (Fig. 4B), as were reporter responses to these agonists in COV434 and KGN granulosa cells (data not shown). 


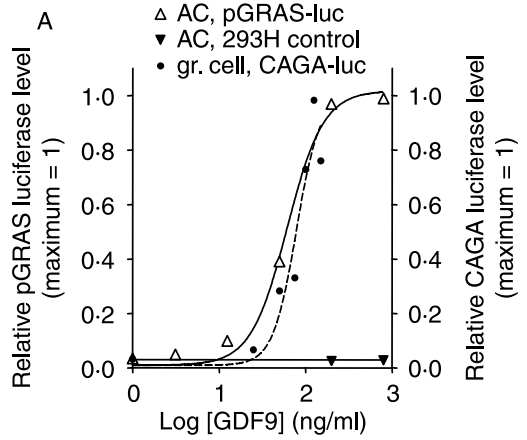

B AC, pGRAS-luc
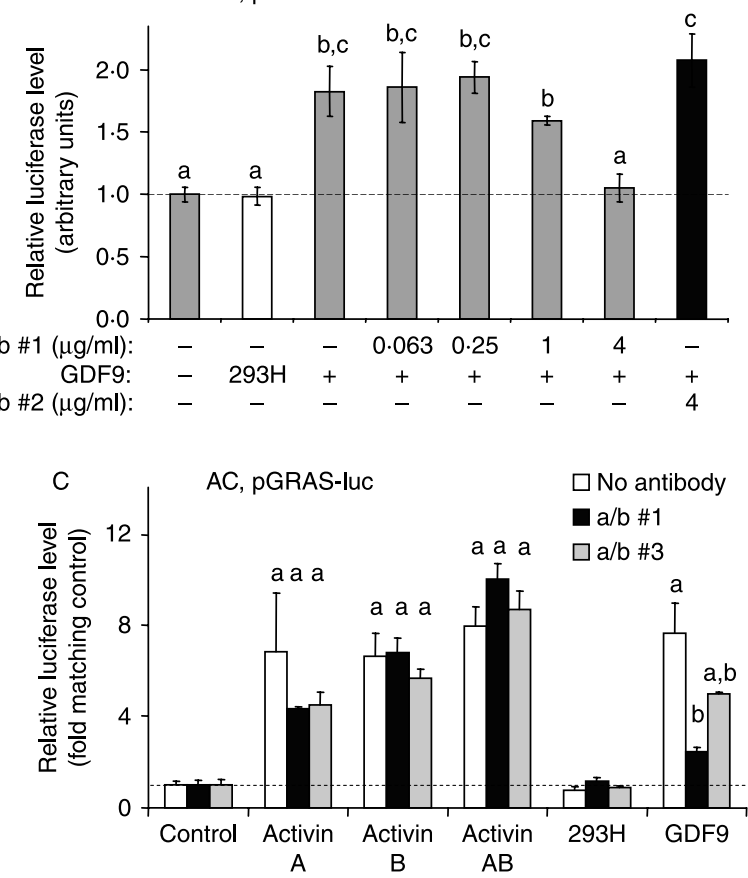

Figure 3 Characterisation of pGRAS-luc reporter responses to GDF9 in AC cells. (A) To determine the concentration dependence of GDF9 action, AC cell cultures that had been transiently transfected with pGRAS-luc, and maintained overnight in medium containing $10 \%$ FBS, were subsequently treated for $6 \mathrm{~h}$ with logarithmically graded concentrations of GDF9 or matching dilutions of the $293 \mathrm{H}$ control in $0.25 \mathrm{ml}$ medium containing $10 \%$ AS. Data at each point for the pGRAS-luc curve represent the average result \pm s.D. obtained from replicate amplifications of single samples obtained in one experiment, to conserve stocks of GDF9. A similar pattern was obtained in a second experiment. These data for GDF9 induction of pGRAS-luc expression in AC cells were compared with similar data for the induction of CAGA-luc expression by GDF9 in transiently transfected mouse mural granulosa (gr.) cells (previously published data from Figure 6 of (Gilchrist et al. 2006)) during $48 \mathrm{~h}$. For each sigmoidal curve, the luciferase response data have been normalised to the matching maximum level of expression, estimated by nonlinear regression analysis using GraphPad Prism software. This panel also shows the lack of effect by matching dilutions of the $293 \mathrm{H}$ control in the AC cells. (B) To immunoneutralise GDF9 activity, GDF9 (50 ng/ml) or a matching dilution of its $293 \mathrm{H}$ control preparation was mixed $1: 1$
Lack of GDF9 effects on FSH secretion by rat and mouse gonadotrophs

Although mouse L $\beta$ T2 gonadotroph expression of pGRASluc was not specifically induced by GDF9 (see above), it was recently suggested (Safwat et al. 2005) that SMAD-independent signalling plays a significant part in activin induction of FSH production by the gonadotroph, which represents a more physiological endpoint. We therefore examined the potential for GDF9 to display either 1) autocrine actions on FSH synthesis and secretion by gonadotrophs in the manner of activin that is subject to antagonism by inhibin (Corrigan et al. 1991, Li et al. 1998) or 2) synergism with activin to stimulate FSH production in the manner of BMP (Lee et al. 2007b, Nicol et al. 2008). However, GDF9 $(1-50 \mathrm{ng} / \mathrm{ml})$ did not significantly increase FSH secretion (Fig. 5) or FSH cell content (data not shown) in gonadotroph-containing primary cultures of adult male rat anterior pituitary cells in either the absence or presence of FSH-suppressing concentrations of inhibin A or B (each $0.05 \mathrm{nmol} / \mathrm{l}$ ) over a three-day period (Fig. 5A). GDF9 also did not block or enhance the twofold stimulation of $\mathrm{FSH}$ secretion by either activin A or B (each $0.5 \mathrm{nmol} / \mathrm{l}$ ) in such cultures (Fig. 5B). Moreover, GDF9 alone at concentrations up to $50 \mathrm{ng} / \mathrm{ml}$ failed to modify FSH secretion or storage by L $\beta T 2$ gonadotrophs in the presence of $0 \cdot 2 \%$ FBS (data not shown). Progressive increases in FSH secretion from rat gonadotrophs that occurred in response to concentrations of GDF9 above $50 \mathrm{ng} / \mathrm{ml}$

(vol:vol) with culture medium (control), increasing dilutions of a polyclonal antibody $(\mathrm{a} / \mathrm{b})$ preparation directed against a recombinant mouse GDF9 protein (a/b \#1;0.063-4 $\mu \mathrm{g} / \mathrm{ml}$ final concentration in culture medium), or a matching dilution of a polyclonal $\mathrm{a} / \mathrm{b}$ preparation directed against a recombinant human BMP-15 protein ( $\mathrm{a} / \mathrm{b} \# 2 ; 4 \mu \mathrm{g} / \mathrm{ml}$ final concentration), and mixtures were left standing for $60 \mathrm{~min}$ at $37^{\circ} \mathrm{C}$. Replicate cultures of AC cells were then treated overnight with the GDF9 $(25 \mathrm{ng} / \mathrm{ml}$ final concentration; filled bars) or its $293 \mathrm{H}$ control (open bar), in the absence or presence of $a / b$, after which luciferase levels were determined in duplicate in triplicate samples for each treatment. Plotted data (average \pm s.D.) were obtained after normalising results of treatments against the level of luciferase observed in untreated cultures ( $=1$, indicated by the broken horizontal line). Results labelled with a common letter ( $\mathrm{a}, \mathrm{b}$ or $\mathrm{c})$ are not significantly different $(P>0 \cdot 05)$. (C) To examine the specificity of action of the GDF9 immunoneutralising antibody, activins $A, B$ and $A B$ (each $2 \mathrm{nmol} / \mathrm{l}$ ), GDF9 $(50 \mathrm{ng} / \mathrm{ml})$ or a matching dilution of its $293 \mathrm{H}$ control preparation was mixed 1:1 (vol:vol) with culture medium (control (No antibody), open bars), GDF9 immunoneutralising antibody (a/b \#1; $4 \mu \mathrm{g} / \mathrm{ml}$ final concentration in culture medium; black bars), or a matching dilution of a polyclonal $\mathrm{a} / \mathrm{b}$ preparation directed against the N-terminal sequence of human GDF9 (a/b \#3;4 $\mu \mathrm{g} / \mathrm{ml}$ final concentration; grey bars), and mixtures were left standing for $60 \mathrm{~min}$ at $37^{\circ} \mathrm{C}$. Replicate cultures of AC cells were then treated overnight with activin isoform ( $1 \mathrm{nmol} / \mathrm{l}$ final concentration), GDF9 (25 ng/ml final concentration) or its $293 \mathrm{H}$ control, in the absence or presence of $\mathrm{a} / \mathrm{b}$. Other details are as for $\mathrm{B}$ above. a signifies results that significantly differ from those obtained for the matching untreated (control) and $293 \mathrm{H}$ control-treated cells, respectively $(P<0 \cdot 01)$. b signifies results that significantly differ from those obtained for the matching antibody-free treatment group $(P<0 \cdot 05)$. 
A

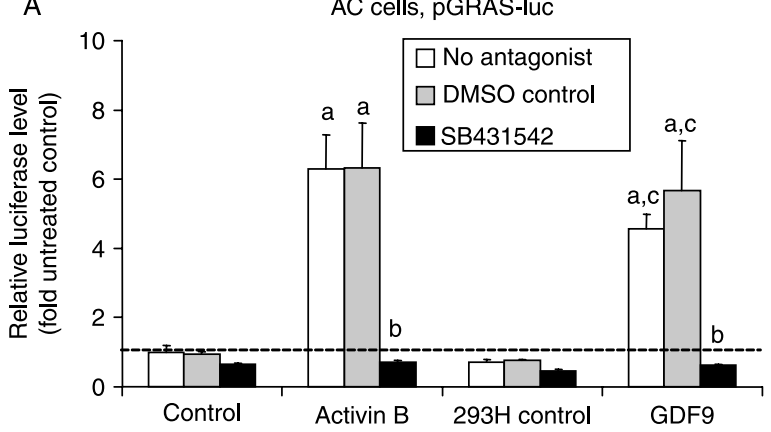

B

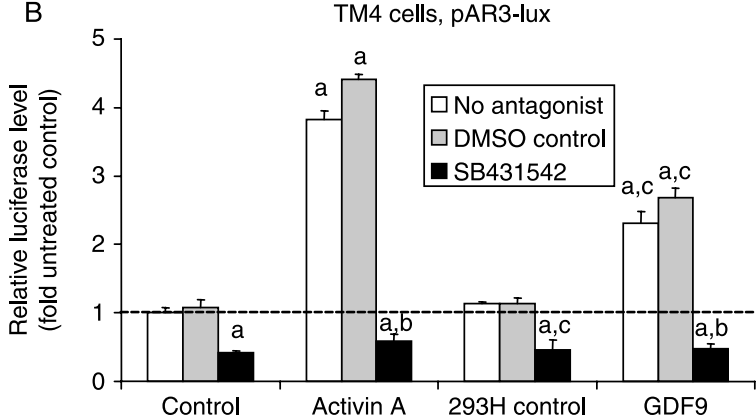

Figure 4 Antagonism of GDF9 activity by SB431542 in extraovarian cell types. (A) AC cells that had been transiently transfected with the reporter, pGRAS-luc, were stabilised overnight in medium containing $10 \%$ FBS, incubated for $24 \mathrm{~h}$ with no treatment, the ALK4/5/7 inhibitor, SB431542 (20 $\mathrm{mol} / \mathrm{l})$, or its vehicle, dimethyl sulfoxide (DMSO, $0.08 \%$ ), in medium containing $10 \%$ AS, then duplicate cultures from each pre-treatment group were incubated a further $24 \mathrm{~h}$ under the same conditions in fresh medium with or without inhibitor/vehicle that additionally contained no agonist (control), activin B $(2 \mathrm{nmol} / \mathrm{l})$, GDF9 $(50 \mathrm{ng} / \mathrm{ml})$, or a matching dilution of its $293 \mathrm{H}$ control, after which luciferase levels were determined. Plotted data (average \pm s.D.) were obtained after normalising results of treatments against the level of luciferase observed in untreated cultures $(=1$, indicated by the broken horizontal line). (B) TM4 cells that had been transiently transfected with the reporter, pAR3-lux, were pre- and concurrently treated with SB431542 as above, and additionally treated with no agonist (control), activin A (2 nmol/l), GDF9 $(50 \mathrm{ng} / \mathrm{ml})$, or a matching dilution of its $293 \mathrm{H}$ control. Other details are as for $\mathrm{A}$. In each panel, $a, b$ and $c$ signify results that significantly differ from those obtained for the matching medium-treated (no antagonist) or vehicle-treated (DMSO control) cells (a), ligand+DMSO-treated cells (b), and $293 \mathrm{H}+$ DMSO-treated cells $(\mathrm{c})$, respectively $(P<0 \cdot 01)$ in each case.

$(\log (\mathrm{GDF} 9)=1 \cdot 7)$ were also elicited by the $293 \mathrm{H}$ control at matching dilutions in these assays, indicating non-specific effects (Fig. 5C). These results confirmed the insensitivity of the gonadotroph to GDF9 stimulation.

\section{Discussion}

The best characterised site of GDF9 expression in mammals is the ovary where, depending on the species, this TGF- $\beta$ superfamily member is principally or exclusively expressed by the oocyte (McGrath et al. 1995, Chang et al. 2002, Juengel \&
McNatty 2005, Gilchrist \& Thompson 2007). Secreted GDF9 provides essential inputs to the follicular granulosa cells, particularly the cumulus granulosa cells that envelop and support the oocyte (Dong et al. 1996, Hanrahan et al. 2004, Gilchrist \& Thompson 2007, Su et al. 2008). Although GDF9 is sometimes referred to as an oocyte-specific factor, it is also expressed outside the ovary, most notably for the present studies in the testis (mouse, rat, cow and human), pituitary (sheep and human) and adrenal cells (mouse and human; Fitzpatrick et al. 1998, Pennetier et al. 2004, Faure et al. 2005, Farnworth et al. 2006b, Nicholls et al. 2009). Regulatory elements have been identified in the mouse GDF9 gene promoter that allow tissue-specific control of its expression (Yan et al. 2006). Whether GDF9 shows activity in extraovarian cell types had not been explored until recently (Nicholls et al. 2009). The present studies identify several cell types, but particularly L $\beta$ T 2 and AC cell lines that model gonadotroph and foetal adrenocortical cells respectively, as potential sources of GDF9. The AC, L $\beta$ T2 gonadotroph, TM3 Leydig and TM4 Sertoli cell lines all express mRNA encoding the binding/signalling proteins thought necessary for conferring responsiveness to GDF9 (Farnworth et al. 2007). The cell types that are modelled by these cell line therefore represent potential targets of local (autocrine/ paracrine) GDF9 action. In partial agreement with this proposal, GDF9 increases the expression of activin/TGF- $\beta$ responsive reporters in AC and TM4 cells. Surprisingly, GDF9 poorly activates the gonadotroph and Leydig cell types for the endpoints that were measured.

GDF9 signalling differs from that by other BMPRIIbinding agonists, which activate R-SMADs 1, 5 and/or 8, because GDF9 instead recruits ALK5, and consequently activates R-SMADs 2 and/or 3 (Roh et al. 2003, Mazerbourg
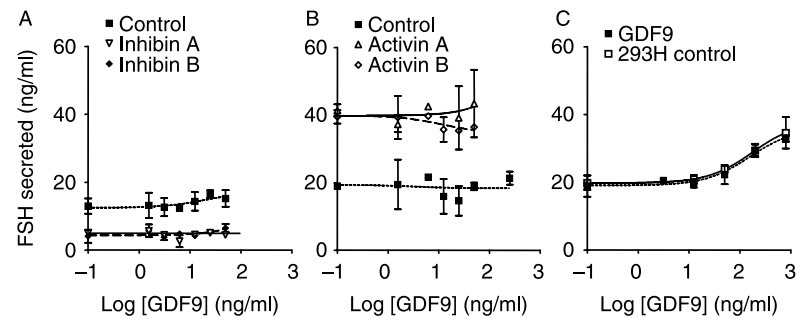

Figure 5 Effects of GDF9 on secreted FSH levels in rat primary pituitary cell cultures. Cultures prepared from adult male rat anterior pituitary glands were treated with the indicated levels of recombinant mouse GDF9 for $3 \mathrm{~d}$ in serum-free medium containing $10 \%$ AS. FSH levels in the pituitary cell-conditioned media were measured by RIA. (A) GDF9 was applied in the absence (control, $\boldsymbol{\square}$, dotted line) or presence of FSH-suppressing levels of inhibin A $(\nabla$, broken line) or B ( $\bullet$, full line; each $0.05 \mathrm{nmol} / \mathrm{l})$. (B) GDF9 was applied in the absence (control, $\mathbf{\square}$, dotted line) or presence of $\mathrm{FSH}$-stimulating levels of activin $\mathrm{A}(\triangle$, full line) or $\mathrm{B}(\bullet$, broken line; each $0.5 \mathrm{nmol} / \mathrm{I})$. (C) The effects of GDF9 ( $\mathbf{\square}$, dotted line) were compared with those of matching dilutions of the $293 \mathrm{H}$ control ( $\square$, full line). Results (ng FSH/ml medium) from triplicate wells are mean \pm s.D. of data obtained by RIA, and curves were fitted by nonlinear regression using GraphPad Prism software. 
\& Hsueh 2006). GDF9 activation of R-SMAD 2/3-responsive reporters in AC and TM4 cells confirmed predictions that were based on the expression of mRNA encoding these R-SMADs, BMPRII and ALK5 by both cell lines (Farnworth et al. 2007). GDF9 activates pGRAS-luc reporter expression in AC cells with similar potency to its induction of CAGA-luc expression by mouse mural granulosa cells (Gilchrist et al. 2006). Responses of the latter reporter are selectively mediated by R-SMAD 3, but not R-SMAD 2, in combination with co-SMAD 4 (Dennler et al. 1998), whereas the pGRAS-luc responses to activin/TGF- $\beta$ require FoxL2, a member of the forkhead family of DNA binding proteins, and AP-1, in addition to the SMADs (Ellsworth et al. 2003). On the other hand, responses to pAR3-lux reflect the activation of its three activin-responsive elements by a complex of phosphorylated R-SMAD 2 and a forkhead-containing DNAbinding protein (either FAST1 or FAST2; Hayashi et al. 1997). TM4 cells accordingly required co-transfection of pAR3-lux with FAST2 to give strong responses to agonists. It is notable that R-SMAD 3 acts as an inhibitor in this system (Labbe et al. 1998, Nagarajan et al. 1999). The ligand and $\mathrm{R}-\mathrm{SMAD}$ specificities of the reporter responses, and ablation of GDF9 actions by SB431542, in AC and TM4 cells show that GDF9 stimulates these extra-ovarian cell types via ALK4, 5 or 7 activation of R-SMADs $2 / 3$, as previously established using granulosa cells (Kaivo-Oja et al. 2003, Roh et al. 2003, Gilchrist et al. 2006) and confirmed with human granulosa cell lines in the present work. The observation that TGF- $\beta$ isoforms elicit responses from the pAR3-lux reporter gene in TM4 cells provides independent evidence for their expression of functional ALK5 receptors, but similar evidence could not be obtained with TGF- $\beta$ in AC cells because they lack T $\beta$ RII. However, both cell lines also express ALK4, and AC cells express ALK7, so more work is required to completely define the extra-ovarian signalling pathway(s) used by GDF9.

The stimulation of pGRAS-luc expression by our partially purified mouse GDF9 preparation in AC cells is immunoneutralised by a commercially available GDF9 antibody, whereas other antisera are ineffective. Moreover, the active antibody does not suppress reporter responses to activin isoforms. Together with the data showing lack of action of the matched $293 \mathrm{H}$ control preparation, and the previous immunoneutralisation of this GDF9 preparation with a different antibody, mAB-GDF9-53 (Gilchrist et al. 2004), the current immunoneutralisation results confirm that the responses to the partially purified preparation of GDF9 in extra-ovarian cell types reflect specific actions of the hormone.

The demonstration by RT-PCR that AC cells express Gdf9 mRNA confirms our previous observation using microarray analysis (Farnworth et al. 2006b). The AC cell line is believed to be derived from the $\mathrm{X}$-zone cells of the foetal adrenal cortex, based in part on its expression of Cyp 17 mRNA and metabolism of progesterone substrate to 17 $\alpha$-hydroxyprogesterone (Kananen et al. 1996, Farnworth et al. 2006b). It is therefore notable that foetal and neonatal mouse adrenal glands express Gdf9 mRNA much more abundantly than do adult male and female adrenal tissues. Immunohistochemical analysis of the ontogeny of GDF9 expression in the mouse adrenal gland established that expression is confined to cortical cells, especially those in the juxtamedullary $\mathrm{X}$-zone of the foetal adrenal, and that the levels of specific staining for GDF9 expression in the adrenal cortex decline after birth. These results reinforce the foetal adrenocortical nature of the AC cell model. More importantly, they suggest that GDF9 may play a local role in the adrenal during foetal life, and hence the actions of GDF9 on AC cells as a model of the foetal adrenal are the subject of ongoing studies in our laboratory. Ontogeny of GDF9 expression in human extra-ovarian tissues has not been investigated. However, it is notable that low level GDF9 expression was found in a pool of human adrenal mRNA representing multiple individuals and covering a wide age range (Fitzpatrick et al. 1998).

Rat pituitary cells in culture and mouse pituitary glands were found to express mRNA encoding GDF9, confirming and extending the previously observed expression of Gdf9 mRNA by the human and sheep pituitary (Fitzpatrick et al. 1998, Faure et al. 2005), but the pituitary cell type(s) responsible could not be identified in these circumstances. Our immunohistochemical studies showed that cells of particularly the anterior lobe, but also the neurointermediate lobe, of the mouse pituitary express GDF9 protein. With respect to the anterior lobe, our finding that $\mathrm{L} \beta \mathrm{T} 2$ cells strongly express Gdf9 mRNA suggests that gonadotrophs are a potential source of GDF9, which may act locally within the pituitary gland. However, gonadotrophs form a small subpopulation (below 20\%) of cells within the anterior pituitary. They are therefore unlikely to be the only cell types that produce GDF9, since the immunohistochemical data revealed that more than $50 \%$ of cells within the mouse anterior pituitary are sources of GDF9 protein.

FSH secretion by L $\beta$ T2 gonadotrophs and gonadotrophcontaining primary cultures of adult male rat pituitary cells is stimulated by activin isoforms, reflecting the induction of FSH $\beta$-subunit transcription, which is at least partly mediated by ALK4 through the activation of R-SMADs 2 and 3 (Dupont et al. 2003, Bernard 2004). GDF9 was therefore expected to act similarly by activating R-SMADs 2 and/or 3 in the BMPRII/ALK5-expressing gonadotrophs. However, GDF9 surprisingly does not modify FSH synthesis/secretion by rat gonadotrophs in primary culture, or the expression of pGRAS-luc or secretion of FSH by mouse L $\beta$ T2 gonadotrophs. This pattern nevertheless accords with a recent study in which GDF9 had minimal effects on FSH secretion in primary pituitary cell cultures prepared from sheep (Young et al. 2008). By contrast, FSH secretion is stimulated by the closely related ligand, BMP-15 (Otsuka \& Shimasaki 2002), which instead signals via R-SMADs $1 / 5 / 8$ (Moore et al. 2003). Apart from R-SMADs, additional signalling molecules are activated by activin in gonadotrophs (Dupont et al. 2003, Safwat et al. 2005), and such SMAD-independent signalling pathways can play major or supplementary roles in mediating 
TGF- $\beta$ superfamily agonist actions (Piek et al. 1999, Moustakas \& Heldin 2005). For instance, TAK1 (listed as MAP3K7 in MGI Database), a TGF- $\beta$ activated MEKKK, is reported to mediate the stimulation of $\mathrm{FSH} \beta$ gene transcription by activin in L $\beta$ T2 gonadotrophs (Safwat et al. 2005). It remains to be determined whether differential activation of TAK1 by activin, but not GDF9, might be the basis for the relative insensitivity of gonadotrophs to bioactive GDF9.

Mouse and rat testes express Gdf9 mRNA (this study; (Fitzpatrick et al. 1998, Nicholls et al. 2009)). Gdf9 mRNA is localised to germ cells, including the more mature (pachytene) spermatocytes in the mouse, and round spermatids in both rat and mouse, but little or no evidence was obtained for expression by Leydig or Sertoli cells. Little Gdf9 mRNA was evident by real-time RT-PCR in TM3 Leydig and TM4 Sertoli cell lines, and previous examination of TM3 cell expression of Gdf9 by northern blot analysis was negative (Fitzpatrick et al. 1998). Although unlikely to be sources of GDF9, TM3 and TM4 cells were nevertheless expected to respond to GDF9, activin and TGF- $\beta$ because they express mRNA encoding the requisite receptors and signalling molecules for all of these agonists. In addition, Sertoli cells perform an analogous role in the testis to that played by ovarian granulosa cells, and might therefore be expected to respond to any GDF9 made by the germ cells. GDF9 accordingly activates R-SMAD2/3 signalling via ALK4, 5 or 7 in TM4 cells in a similar way to its activation of the granulosa cell lines, KGN and COV434. This supports and extends our recent evidence that rat Sertoli cells co-express BMPRII and ALK5, and that GDF9 modifies Sertoli cell functions in vitro using a signalling pathway that is blocked by SB431542 (Nicholls et al. 2009). In contrast to TM4 cells, TM3 cells do not respond specifically to GDF9, although their robust responses to TGF- $\beta$ and activin isoforms provide indirect evidence that TM3 cell expression of mRNA for ALK5 receptor and R-SMADs 2 and 3 (Farnworth et al. 2007) gives rise to functional proteins. As with gonadotrophs, there seems to be some characteristic of TM3 Leydig cells that prevents their activation by GDF9.

We conclude that GDF9 is expressed in foetal and neonatal mouse adrenal, as well as AC cells and pituitary gonadotrophs. Recombinant mouse GDF9 stimulates expression of $\mathrm{R}$-SMAD 2/3-responsive luciferase reporter constructs in cell lines that model foetal adrenocortical and Sertoli cells, demonstrating a potential for autocrine/paracrine stimulation of these cell types by GDF9 in vivo. The lack of specific GDF9 actions in TM3 cells, and two different gonadotroph preparations, raises the possibility that expression of BMPRII, ALK-5, and R-SMADs 2 and 3 are necessary (Mazerbourg \& Hsueh 2006), but may not be sufficient, for a cell to respond robustly to GDF9. These studies nevertheless establish that GDF9 acts on receptive extra-ovarian cell types through a pathway involving ALK4/5/7 and R-SMAD2/3, as it does in its classical target, the ovarian granulosa cell.

\section{Declaration of interest}

The authors declare that there is no conflict of interest that could be perceived as prejudicing the impartiality of the research reported.

\section{Funding}

The National Health and Medical Research Council of Australia funded this study through Program Grants (Reg Key Nos 983212 \& 241000), and through Fellowships for JKF (Reg Key Nos 198705 and 441101), CAH (Reg Key No. 388920), and RBG (Reg Key No. 465415).

\section{Acknowledgements}

The authors acknowledge the gift of crude inhibins A and B from Biotech Australia (Sydney, Australia), the pGRAS-luc reporter construct from Dr Buffy Ellsworth (Colorado State University, CO), and generous provision of the purified inhibins by Assoc Prof. David Robertson and Yogesh Makanji. Thanks also to Prof. Ilpo Huhtaniemi (Imperial College, London, UK) and Dr Nafis Rahman (University of Turku, Finland) for providing the $\mathrm{C} \alpha-1$ cell line from which AC cells are derived, and Dr Pam Mellon for providing the L $\beta T 2$ cells, Dr A F Parlow (National Hormone and Pituitary Program, Torrance, CA) for provision of RIA reagents, Hui Kheng Chua for mouse tissue samples, and Fang Wang for performing FSH ELISAs.

\section{References}

Bernard DJ 2004 Both SMAD2 and SMAD3 mediate activin-stimulated expression of the follicle-stimulating hormone beta subunit in mouse gonadotrope cells. Molecular Endocrinology 18 606-623.

de Caestecker M 2004 The transforming growth factor- $\beta$ superfamily of receptors. Cytokine and Growth Factor Reviews 15 1-11.

Chand AL, Ooi GT, Harrison CA, Shelling AN \& Robertson DM 2007 Functional analysis of the human inhibin $\alpha$ subunit variant A257T and its potential role in premature ovarian failure. Human Reproduction $\mathbf{2 2}$ 3241-3248.

Chang H, Brown CW \& Matzuk MM 2002 Genetic analysis of the mammalian transforming growth factor- $\beta$ superfamily. Endocrine Reviews 23 $787-823$

Corrigan AZ, Bilezikjian LM, Carroll RS, Bald LN, Schmelzer CH, Fendly BM, Mason AJ, Chin WW, Schwall RH \& Vale W 1991 Evidence for an autocrine role of activin B within rat anterior pituitary cultures. Endocrinology 128 1682-1684.

Dennler S, Itoh S, Vivien D, ten Dijke P, Huet S \& Gauthier JM 1998 Direct binding of Smad 3 and Smad4 to critical TGF $\beta$-inducible elements in the promoter of human plasminogen activator inhibitor-type 1 gene. EMBO Journal 17 3091-3100.

Dong J, Albertini DF, Nishimori K, Kumar TR, Lu N \& Matzuk MM 1996 Growth differentiation factor-9 is required during early ovarian folliculogenesis. Nature 383 531-535.

Drummond AE, Dyson M, Thean E, Groome NP, Robertson DM \& Findlay JK 2000 Temporal and hormonal regulation of inhibin protein and subunit mRNA expression by post-natal and immature rat ovaries. Journal of Endocrinology 166 339-354.

Dupont J, McNeilly J, Vaiman A, Canepa S, Combarnous Y \& Taragnat C 2003 Activin signaling pathways in ovine pituitary and L $\beta$ T2 gonadotrope cells. Biology of Reproduction 68 1877-1887.

Ellsworth BS, Burns AT, Escudero KW, Duval DL, Nelson SE \& Clay CM 2003 The gonadotropin releasing hormone $(\mathrm{GnRH})$ receptor activating sequence (GRAS) is a composite regulatory element that interacts with multiple classes of transcription factors including Smads, AP-1 and a forkhead DNA binding protein. Molecular and Cellular Endocrinology 206 93-111.

www.endocrinology-journals.org 
Elvin JA, Yan C, Wang P, Nishimori K \& Matzuk MM 1999 Molecular characterization of the follicle defects in the growth differentiation factor 9-deficient ovary. Molecular Endocrinology 13 1018-1034.

Ethier JF, Farnworth PG, Findlay JK \& Ooi GT 2002 Transforming growth factor- $\beta$ modulates inhibin A bioactivity in the L $\beta \mathrm{T} 2$ gonadotrope cell line by competing for binding to betaglycan. Molecular Endocrinology 16 2754-2763.

Farnworth PG, Robertson DM, de Kretser DM \& Burger HG 1988 Effects of 31 kilodalton bovine inhibin on follicle-stimulating hormone and luteinizing hormone in rat pituitary cells in vitro: actions under basal conditions. Endocrinology 122 207-213.

Farnworth PG, Stanton PG, Wang Y, Escalona R, Findlay JK \& Ooi GT $2006 a$ Inhibins differentially antagonize activin and bone morphogenetic protein action in a mouse adrenocortical cell line. Endocrinology 147 3462-3471.

Farnworth PG, Wang Y, Leembruggen P, Ooi GT, Harrison C, Robertson DM \& Findlay JK $2006 b$ Rodent adrenocortical cells display high affinity binding sites and proteins for inhibin $\mathrm{A}$, and express components required for autocrine signalling by activins and bone morphogenetic proteins. Journal of Endocrinology 188 451-465.

Farnworth PG, Wang Y, Escalona R, Leembruggen P, Ooi GT \& Findlay JK 2007 Transforming growth factor- $\beta$ blocks inhibin binding to different target cell types in a context-dependent manner through dual mechanisms involving betaglycan. Endocrinology 148 5355-5368.

Faure MO, Nicol L, Fabre S, Fontaine J, Mohoric N, McNeilly A \& Taragnat C 2005 BMP-4 inhibits follicle-stimulating hormone secretion in ewe pituitary. Journal of Endocrinology 186 109-121.

Fitzpatrick SL, Sindoni DM, Shughrue PJ, Lane MV, Merchenthaler IJ \& Frail DE 1998 Expression of growth differentiation factor-9 messenger ribonucleic acid in ovarian and nonovarian rodent and human tissues. Endocrinology 139 2571-2578.

Gilchrist RB \& Thompson JG 2007 Oocyte maturation: emerging concepts and technologies to improve developmental potential in vitro. Theriogenology 67 6-15.

Gilchrist RB, Ritter LJ, Cranfield M, Jeffery LA, Amato F, Scott SJ, Myllymaa S, Kaivo-Oja N, Lankinen H, Mottershead DG et al. 2004 Immunoneutralization of growth differentiation factor 9 reveals it partially accounts for mouse oocyte mitogenic activity. Biology of Reproduction $\mathbf{7 1}$ 732-739.

Gilchrist RB, Ritter LJ, Myllymaa S, Kaivo-Oja N, Dragovic RA, Hickey TE, Ritvos O \& Mottershead DG 2006 Molecular basis of oocyte-paracrine signalling that promotes granulosa cell proliferation. Journal of Cell Science 119 3811-3821.

Hanrahan JP, Gregan SM, Mulsant P, Mullen M, Davis GH, Powell R \& Galloway SM 2004 Mutations in the genes for oocyte-derived growth factors GDF9 and BMP15 are associated with both increased ovulation rate and sterility in Cambridge and Belclare sheep (Ovis aries). Biology of Reproduction 70 900-909.

Hayashi H, Abdollah S, Qiu Y, Cai J, Xu YY, Grinnell BW, Richardson MA, Topper JN, Gimbrone MA Jr, Wrana JL et al. 1997 The MAD-related protein Smad7 associates with the TGF $\beta$ receptor and functions as an antagonist of TGF $\beta$ signaling. Cell 89 1165-1173.

Hickey TE, Marrocco DL, Amato F, Ritter LJ, Norman RJ, Gilchrist RB \& Armstrong DT 2005 Androgens augment the mitogenic effects of oocytesecreted factors and growth differentiation factor 9 on porcine granulosa cells. Biology of Reproduction 73 825-832.

Inman GJ, Nicolas FJ, Callahan JF, Harling JD, Gaster LM, Reith AD, Laping NJ \& Hill CS 2002 SB-431542 is a potent and specific inhibitor of transforming growth factor- $\beta$ superfamily type I activin receptor-like kinase (ALK) receptors ALK4, ALK5, and ALK7. Molecular Pharmacology 62 65-74.

Juengel JL \& McNatty KP 2005 The role of proteins of the transforming growth factor- $\beta$ superfamily in the intraovarian regulation of follicular development. Human Reproduction Update 11 143-160.

Kaivo-Oja N, Bondestam J, Kamarainen M, Koskimies J, Vitt U, Cranfield M, Vuojolainen K, Kallio JP, Olkkonen VM, Hayashi M et al. 2003 Growth differentiation factor-9 induces Smad2 activation and inhibin B production in cultured human granulosa-luteal cells. Journal of Clinical Endocrinology and Metabolism 88 755-762.

Kananen K, Markkula M, Mikola M, Rainio EM, McNeilly A \& Huhtaniemi I 1996 Gonadectomy permits adrenocortical tumorigenesis in mice transgenic for the mouse inhibin $\alpha$-subunit promoter/simian virus 40 T-antigen fusion gene: evidence for negative autoregulation of the inhibin $\alpha$-subunit gene. Molecular Endocrinology 10 1667-1677.

Labbe E, Silvestri C, Hoodless PA, Wrana JL \& Attisano L 1998 Smad2 and Smad3 positively and negatively regulate TGF $\beta$-dependent transcription through the forkhead DNA-binding protein FAST2. Molecular Cell 2 109-120.

Lee GS, Kim HS, Hwang WS \& Yun SH 2007a Characterization of porcine growth differentiation factor-9 and its expression in oocyte maturation. Molecular Reproduction and Development 75 707-714.

Lee KB, Khivansara V, Santos MM, Lamba P, Yuen T, Sealfon SC \& Bernard DJ $2007 b$ Bone morphogenetic protein 2 and activin A synergistically stimulate follicle-stimulating hormone $\beta$ subunit transcription. Journal of Molecular Endocrinology 38 315-330.

Li MD, Macdonald GJ, Wise T \& Ford JJ 1998 Positive association between expression of follicle-stimulating hormone $\beta$ and activin $\beta \mathrm{B}$-subunit genes in boars. Biology of Reproduction 59 978-982.

Makanji Y, Harrison CA, Stanton PG, Krishna R \& Robertson DM 2007 Inhibin $\mathrm{A}$ and $\mathrm{B}$ in vitro bioactivities are modified by their degree of glycosylation and their affinities to betaglycan. Endocrinology 148 2309-2316.

Mason AJ, Farnworth PG \& Sullivan J 1996 Characterization and determination of the biological activities of noncleavable high molecular weight forms of inhibin A and activin A. Molecular Endocrinology $\mathbf{1 0}$ $1055-1065$.

Massague J 1998 TGF- $\beta$ signal transduction. Annual Review of Biochemistry 67 753-791.

Mather JP 1982 Ceruloplasmin, a copper-transport protein, can act as a growth promoter for some cell lines in serum-free medium. In Vitro 18 990-996.

Mazerbourg S \& Hsueh AJ 2006 Genomic analyses facilitate identification of receptors and signalling pathways for growth differentiation factor 9 and related orphan bone morphogenetic protein/growth differentiation factor ligands. Human Reproduction Update 12 373-383.

Mazerbourg S, Klein C, Roh J, Kaivo-Oja N, Mottershead DG, Korchynskyi O, Ritvos O \& Hsueh AJ 2004 Growth differentiation factor-9 signaling is mediated by the type I receptor, activin receptor-like kinase 5. Molecular Endocrinology 18 653-665.

McGrath SA, Esquela AF \& Lee SJ 1995 Oocyte-specific expression of growth/differentiation factor-9. Molecular Endocrinology 9 131-136.

Moore RK, Otsuka F \& Shimasaki S 2003 Molecular basis of bone morphogenetic protein-15 signaling in granulosa cells. Journal of Biological Chemistry 278 304-310.

Moustakas A \& Heldin CH 2005 Non-Smad TGF- $\beta$ signals. Journal of Cell Science 118 3573-3584.

Nagarajan RP, Liu J \& Chen Y 1999 Smad3 inhibits transforming growth factor- $\beta$ and activin signaling by competing with Smad4 for FAST-2 binding. Journal of Biological Chemistry 274 31229-31235.

Nicholls PK, Harrison CA, Gilchrist RB, Farnworth PG \& Stanton PG 2009 Growth differentiation factor 9 (GDF9) is a germ-cell regulator of Sertoli cell function. Endocrinology 150 2481-2490.

Nicol L, Faure MO, McNeilly JR, Fontaine J, Taragnat C \& McNeilly AS 2008 Bone morphogenetic protein-4 interacts with activin and GnRH to modulate gonadotrophin secretion in L $\beta \mathrm{T} 2$ gonadotrophs. Journal of Endocrinology 196 497-507.

Nishi Y, Yanase T, Mu Y, Oba K, Ichino I, Saito M, Nomura M, Mukasa C, Okabe T, Goto K et al. 2001 Establishment and characterization of a steroidogenic human granulosa-like tumor cell line, KGN, that expresses functional follicle-stimulating hormone receptor. Endocrinology 142 437-445.

Otsuka F \& Shimasaki S 2002 A novel function of bone morphogenetic protein- 15 in the pituitary: selective synthesis and secretion of FSH by gonadotropes. Endocrinology 143 4938-4941. 
Pennetier S, Uzbekova S, Perreau C, Papillier P, Mermillod P \& Dalbies-Tran R 2004 Spatio-temporal expression of the germ cell marker genes MATER, ZAR1, GDF9, BMP15, and VASA in adult bovine tissues, oocytes, and preimplantation embryos. Biology of Reproduction $\mathbf{7 1}$ 1359-1366.

Pernasetti F, Vasilyev VV, Rosenberg SB, Bailey JS, Huang HJ, Miller WL \& Mellon PL 2001 Cell-specific transcriptional regulation of folliclestimulating hormone- $\beta$ by activin and gonadotropin-releasing hormone in the L $\beta$ T2 pituitary gonadotrope cell model. Endocrinology 142 2284-2295.

Piek E, Heldin CH \& Ten Dijke P 1999 Specificity, diversity, and regulation in TGF- $\beta$ superfamily signaling. FASEB Journal 13 2105-2124.

Rahman NA, Kiiveri S, Siltanen S, Levallet J, Kero J, Lensu T, Wilson DB, Heikinheimo MT \& Huhtaniemi IT 2001 Adrenocortical tumorigenesis in transgenic mice: the role of luteinizing hormone receptor and transcription factors GATA-4 and GATA-6. Reproductive Biology 1 5-9.

Rilianawati, Paukku T, Kero J, Zhang FP, Rahman N, Kananen K \& Huhtaniemi I 1998 Direct luteinizing hormone action triggers adrenocortical tumorigenesis in castrated mice transgenic for the murine inhibin $\alpha$-subunit promoter/simian virus $40 \mathrm{~T}$-antigen fusion gene. Molecular Endocrinology 12 801-809.

Roh JS, Bondestam J, Mazerbourg S, Kaivo-Oja N, Groome N, Ritvos O \& Hsueh AJ 2003 Growth differentiation factor-9 stimulates inhibin production and activates Smad2 in cultured rat granulosa cells. Endocrinology $144172-178$

Safwat N, Ninomiya-Tsuji J, Gore AJ \& Miller WL 2005 Transforming growth factor $\beta$-activated kinase 1 is a key mediator of ovine folliclestimulating hormone $\beta$-subunit expression. Endocrinology 146 4814-4824.
Su YQ, Sugiura K, Wigglesworth K, O’Brien MJ, Affourtit JP, Pangas SA, Matzuk MM \& Eppig JJ 2008 Oocyte regulation of metabolic cooperativity between mouse cumulus cells and oocytes: BMP15 and GDF9 control cholesterol biosynthesis in cumulus cells. Development $\mathbf{1 3 5}$ 111-121.

Vitt UA, Mazerbourg S, Klein C \& Hsueh AJ 2002 Bone morphogenetic protein receptor type II is a receptor for growth differentiation factor-9. Biology of Reproduction 67 473-480.

Yan C, Elvin JA, Lin YN, Hadsell LA, Wang J, DeMayo FJ \& Matzuk MM 2006 Regulation of growth differentiation factor 9 expression in oocytes in vivo: a key role of the E-box. Biology of Reproduction 74 999-1006.

Young JM, Juengel JL, Dodds KG, Laird M, Dearden PK, McNeilly AS, McNatty KP \& Wilson T 2008 The activin receptor-like kinase 6 Booroola mutation enhances suppressive effects of bone morphogenetic protein 2 (BMP2), BMP4, BMP6 and growth and differentiation factor-9 on FSH release from ovine primary pituitary cell cultures. Journal of Endocrinology 196 251-261.

Zhang H, Vollmer M, De Geyter M, Litzistorf Y, Ladewig A, Durrenberger M, Guggenheim R, Miny P, Holzgreve W \& De Geyter C 2000 Characterization of an immortalized human granulosa cell line (COV434). Molecular Human Reproduction 6 146-153.

\section{Received in final form 27 April 2009 \\ Accepted 2 June 2009}

Made available online as an Accepted Preprint 2 June 2009 